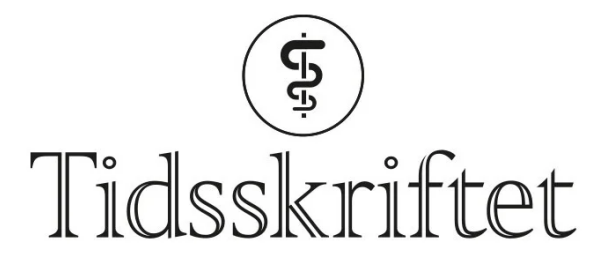

DEN NORSKE LEGEFORENING

\title{
Covid-19 med nedsatt lukte- og smakssans som eneste symptom
}

KORT KASUISTIKK

\section{JØRAN HJELMESAETH}

joran.hjelmeseth@siv.no

Senter for sykelig overvekt i Helse Sør-Øst ved Sykehuset i Vestfold

og

Universitetet i Oslo

Jøran Hjelmesæth er dr.med., spesialist i indremedisin og i nyresykdommer og professor. Han leder Senter for sykelig overvekt og Nasjonalt råd for ernæring.

Forfatteren har fylt ut ICMJE-skjemaet og oppgir ingen interessekonflikter.

\section{DAGFINN SKAARE}

Mikrobiologisk avdeling

Smittevernseksjonen, Fagavdelingen

Sykehuset i Vestfold

Dagfinn Skaare er ph.d., spesialist i medisinsk mikrobiologi og overlege. Han leder en

forskningsgruppe innenfor antibiotikaresistens finansiert av strategiske forskningsmidler fra Helse Sør-Øst.

Forfatteren har fylt ut ICMJE-skjemaet og oppgir ingen interessekonflikter.

\section{Et ektepar opplevde at konen fikk manglende luktesans og mannen fikk manglende smakssans noen dager etter nærkontakt med en covid-19-smittet person. De hadde ingen andre symptomer, men fikk begge to påvist sars-CoV-2.}

En kvinne i 6o-årene stekte vafler og reagerte på at hun ikke kjente den gode vaffellukten. Hennes svigerfar var innlagt på sykehus med påvist covid-19, og hun hadde vært i nærkontakt med ham 17 dager før. Via media var hun blitt oppmerksom på at tap av luktesans (anosmi) kunne være et symptom. Hun var fra tidligere frisk og hadde aldri hatt lukt- eller smaksforstyrrelser eller nese/bihule-plager, og brukte ingen faste medisiner. Hun hadde hverken feber, sår hals, hoste eller pustevansker. Ved nærmere ettertanke kom hun frem til at anosmien hadde vart i ti dager. Dette, kombinert med nær forbindelse til et bekreftet covid-19-tilfelle og status som helsepersonell, gjorde at hun ble testet. Prøven var positiv for sars-CoV-2-RNA. Pasienten opplevde ingen andre symptomer enn total anosmi, og både smakssans og appetitt var uendret. 16 dager etter at luktesansen forsvant, kunne pasienten kjenne lukten av en deodorant. 
Pasientens mann, også han i 6o-årene, opplevde å miste smakssansen fullstendig (ageusi) i ni dager. Han hadde vært i kontakt med sin far ti og syv dager før symptomdebut i tillegg til kontakt med sin kone. Han hadde ikke hoste, sår hals eller luftveissymptomer. Både luktesans og appetitt var uendret. Fra tidligere var han operert med Billroth-II for magesår. Av faste medisiner brukte han ezomeprazol $40 \mathrm{mg}$ daglig mot øsofagitt, rivaroksaban $20 \mathrm{mg}$ daglig for atrieflimmer og vitamin $\mathrm{B}_{12}$-injeksjoner $(1 \mathrm{mg})$ hver 6 . uke som substitusjonsbehandling. Heller ikke han hadde tidligere hatt lukt- eller smaksforstyrrelser eller nese/bihule-plager. Siden han var nærkontakt til to bekreftede tilfeller av covid-19 og hadde total ageusi, ble han testet for sars-CoV-2-RNA. Resultatet var positivt. Den tiende dagen merket han søt og syrlig smak av jordbær og etter 13 dager smaken av god lapskaus (umami).

Ved nærmere utspørring kom det frem at også faren/svigerfaren, som er i go-årene, hadde endret smakssans (dysgeusi). Brød smakte papp, og søt mat og drikke, som han vanligvis likte godt, smakte altfor søtt. Han rapporterte også om nedsatt matlyst. Disse symptomene hadde kommet etter symptomdebut og etter at han testet positivt for sars-CoV-2, men nøyaktig tidspunkt er usikkert. Han hadde også tungpustethet, hoste og feberfølelse.

Prøvene fra alle pasientene ble analysert for sars-CoV-2-RNA (E-genet) ved Mikrobiologisk avdeling ved Sykehuset i Vestfold med in-house revers transkriptase-PCR i henhold til anbefalt metode (1․). Prøvene ble tatt (med Transwab) fra svelg og nasofarynks (far/svigerfar og svigerdatter) eller kun nasofarynks ( $₫ ø n n$ ) på hhv. dag 5, 11 og 9 etter symptomdebut. Disse var positive med Ct-verdier på henholdsvis 16,8, 20,7 og 30,5 ( $\varnothing$ kende verdi med synkende viruskonsentrasjon). Basert på data fra lokal validering av analysen indikerer Ctverdiene at antallet viruskopier per mikroliter i prøvene varierte fra cirka $2 \cdot 10^{6}$ hos far til 75 hos sønn.

\section{Diskusjon}

Regjeringens strategi for å bekjempe utbruddet av covid-19 i Norge er basert på at hver smittet person maksimalt skal smitte én person (ㅁ). Det er derfor viktig å identifisere flest mulig smittede og isolere disse til de har inntil én ukes symptomfrihet (3). Modellering av smittespredning basert på kliniske data fra Kina tyder på at personer med få eller ingen symptomer kan være smittebærere (4.). Det er derfor av betydning også å identifisere slike personer. Kriterier for å teste for sars-CoV-2 i Norge per 1. april 2020 er akutt luftveisinfeksjon med feber, hoste eller tungpustethet hos utvalgte grupper, deriblant helsepersonell, som også kan vurderes for testing ved mildere akutte luftveissymptomer (5). Tilsvarende benyttes kriteriet akutt respirasjonssykdom (acute respiratory illness) i Verdens helseorganisasjons kasusdefinisjon (ㅌ․,7.). Personer med akutt luftveisinfeksjon som ikke omfattes av testkriteriene, anbefales å holde seg hjemme inntil ett døgns symptomfrihet (ㅁ). Rådene favner imidlertid ikke personer som har anosmi eller ageusi som eneste symptom. Våre kasuistikker tyder på at slike personer kan utgjøre smittekilder som per i dag går under radaren.

\section{INTERNASJONALE ERFARINGER}

En forskningsgruppe i Milano publiserte nylig en tverrsnittsundersøkelse på forekomsten av lukt- og smaksforstyrrelser hos 59 sars-CoV-2-positive hospitaliserte pasienter. Studien viste at $34 \%$ hadde en slik forstyrrelse, 20 \% før innleggelse og $14 \%$ etter innleggelse (9.). Media har også rapportert om kliniske erfaringer som tyder på at anosmi og ageusi kan

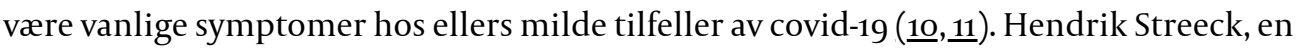
tysk professor i virologi, uttalte nylig til Frankfurter Allgemeine Zeitung at minst to tredeler av alle infiserte $(\mathrm{n}>100$ som ikke var innlagt på sykehus) beskriver tap av lukt og $\operatorname{smak}(\underline{10})$. 
Professor Claire Hopkins, president i British Association of Otorhinolaryngology, understreker at slike symptomer har blitt observert hos smittede personer uten andre klassiske symptomer i Storbritannia, USA, Frankrike og Nord-Italia (11). Hun uttrykker bekymring for at disse kan være skjulte bærere og smittespredere av viruset og foreslår at personer med slike symptomer burde isolere seg selv i minst syv dager (11). Tilsvarende har amerikanske øre-nese-hals-spesialister foreslått at anosmi, hyposmi og dysgeusi i fravær av andre forklarende tilstander legges til på listen over symptomer som skal gi mistanke om covid-19, og at testing og isolering bør vurderes (12).

\section{ACE2-RESEPTORER I NESE- OG MUNNSLIMHINNE}

Peng Zhou og medarbeidere identifiserte og karakteriserte det nye koronaviruset (sarsCoV-2) i tidsskriftet Nature 3. februar 2020 (13). Forfatterne bekreftet også at sars-CoV-2 brukte den samme reseptoren, angiotensinkonverterende enzym 2 (ACE2), som sars-CoV for å komme inn i cellen. I en foreløpig ikke-fagfellevurdert rapport hevdes det at antall og andel ACE2-uttrykkende celler i nese- og munnvev er sammenlignbare med de tilsvarende i lungevev og tykktarm $(\underline{14}, 15)$, og forfatterne lurer på om nese- og munnvev kan være det første som infiseres av sars-CoV-2 (14). Disse resultatene støttes delvis av en annen publikasjon som viste at ACE2-reseptoren var uttrykt på munnslimhinnen, spesielt i tungeepitelceller (16 $)$. I en foreløpig siste ikke-fagfellevurdert rapport hevdes det at støtteceller for lukteepitelet, stamceller og respiratorisk epitel i nesen utrykker to gener som er involvert i transporten av sars-CoV-2 inn i cellen, nemlig ACE2 og TMPRSS2, og at dette kan være mulige mekanismer som gjør at sars-CoV-2-infeksjon kan føre til anosmi (17.).

\section{KONKLUSJON}

En økende mengde empiriske data og enkelte publikasjoner tyder på at lukt- og smaksforstyrrelser kan være symptomer på covid-19, uavhengig av eller samtidig med klassiske symptomer. Begrensede data tyder på at sars-CoV-2 kan infisere munn- og neseslimhinner. Våre kasuistikker viser at pasienter med sars-CoV-2-infeksjon kan ha tap av smak- eller luktesans som eneste symptom. I sum kan disse foreløpige funnene påvirke fremtidig forskning, diagnostikk, forebygging og behandling av covid-19. Norske helsemyndigheter bør vurdere om isolert lukt- og/eller smaksforstyrrelse bør være tilstrekkelig grunnlag for testing av covid-19 og/eller isolering for å begrense smitte.

Pasientene har gitt samtykke til at artikkelen blir publisert.

Takk til pasientene for viktig og godt samarbeid, kommuneoverlegen $i$ Tønsberg for godt samarbeid om prøvetaking og oppfølging av positive prøvesvar, og Inger Lill Anthonisen ved Mikrobiologisk avdeling for bistand med tolkning av molekylcrbiologiske analyseresultater.

Artikkelen er fagfellevurdert.

\section{LITTERATUR}

1. Corman VM, Landt O, Kaiser M et al. Detection of 2019 novel coronavirus (2019-nCoV) by real-time RT-PCR. Euro Surveill 2020; 25: 2000045. [PubMed][CrossRef]

2. Regjeringen. Tiltakene mot koronavirus videreføres. Pressemelding. https://www.regjeringen.no/no/aktuelt/tiltakene-mot-koronavirus-viderefores/id2694682/ Lest 29.3.2020.

3. Folkehelseinstituttet. Hjemmekarantene og hjemmeisolering i forbindelse med covid-19. https://www.fhi.no/nettpub/coronavirus/helsepersonell/hjemmekarantene-og-hjemmeisolering-iforbindelse-med-covid-19/ Lest 29.3.2020. 
4. Li R, Pei S, Chen B et al. Substantial undocumented infection facilitates the rapid dissemination of novel coronavirus (SARS-CoV2). Science 2020;368: eabb3221. [PubMed][CrossRef]

5. Folkehelseinstituttet. Testkriterier for nytt koronavirus (coronavirus).

https://www.fhi.no/nettpub/coronavirus/helsepersonell/testing-og-diagnostikk-for-nytt-koronaviruscoronavirus/ Lest 2.4.2020.

6. World Health Organization. Global Surveillance for human infection with coronavirus disease (COVID-19). https://www.who.int/publications-detail/global-surveillance-for-human-infection-withnovel-coronavirus-(2019-ncov) Lest 29.3.2020.

7. World Health Organization. Health topic: Coronavirus. https://www.who.int/healthtopics/coronavirus\#tab=tab_3 Lest 29.3.2020.

8. Folkehelseinstituttet. Råd når du eller husstandsmedlem har akutt luftveisinfeksjon, men ikke testes for covid-19. https://www.fhi.no/nettpub/coronavirus/rad-til-personer-som-er-smittet-eller-harvart-utsatt-for-smitte/rad-til-deg-som-har-symptomer-pa-akutt-luftveisinfeksjon/ Lest 29.3.2020.

9. Giacomelli A, Pezzati L, Conti F et al. Self-reported olfactory and taste disorders in SARS-CoV-2 patients: a cross-sectional study. Clin Infect Dis 2020; 70: ciaa330. [PubMed][CrossRef]

10. Schmitt PP. „Wir haben neue Symptome entdeckt". Frankfurter Allgemeine 16.3.2020. https://www.faz.net/aktuell/gesellschaft/gesundheit/coronavirus/neue-corona-symptome-entdecktvirologe-hendrik-streeck-zum-virus-16681450.html Lest 29.3.2020.

11. ENT UK. Loss of sense of smell as marker of COVID-19 infection. https://www.entuk.org/loss-sensesmell-marker-covid-19-infection Lest 29.3.2020.

12. AAO-HNS: Anosmia, Hyposmia, and Dysgeusia Symptoms of Coronavirus Disease. American Academy of Otolaryngology - Head and Neck Surgery. AAO-HNS: Anosmia, Hyposmia, and Dysgeusia Symptoms of Coronavirus Disease. https://www.entnet.org/content/aao-hns-anosmia-hyposmia-anddysgeusia-symptoms-coronavirus-disease Lest 3.4.2020.

13. Zhou P, Yang XL, Wang XG et al. A pneumonia outbreak associated with a new coronavirus of probable bat origin. Nature 2020; 579: 270-3. [PubMed][CrossRef]

14. Wu C, Zheng M. Single-cell RNA expression profiling shows that ACE2, the putative receptor of COVID-2019, has significant expression in nasal and mouth tissue, and is co-expressed with TMPRSS2 and not co-expressed with SLC6A19 in the tissues. Preprint.

https://www.researchsquare.com/article/rs-16992/v1 Lest 29.3.2020.

15. Wu C, Zheng M.. Single-cell RNA expression profiling shows that ACE2, the putative receptor of Wuhan 2019-nCoV, has significant expression in the nasal mouth, lung and colon tissues, and tends to be co-expressed with HLA-DRB1 in the four tissues. Preprints 2020; 2020020247.

16. Xu H, Zhong L, Deng J et al. High expression of ACE2 receptor of 2019-nCoV on the epithelial cells of oral mucosa. Int J Oral Sci 2020; 12: 8. [PubMed][CrossRef]

17. Brann DH, Tsukahara T, Weinreb C et al. Non-neural expression of SARS-CoV-2 entry genes in the olfactory epithelium suggests mechanisms underlying anosmia in COVID-19 patients. bioRxiv 2020 doi: 10.1101/2020.03.25.009084. [CrossRef]

Publisert: 3. april 2020. Tidsskr Nor Legeforen. DOI: 10.4045/tidsskr.20.0287

Mottatt 30.3.2020, første revisjon innsendt 31.3.2020, godkjent 3.4.2020.

Publisert under åpen tilgang CC BY-ND. Lastet ned fra tidsskriftet.no 26. april 2023. 